\title{
Enthalpies of Solution of the Nucleic Acid Bases. 5. Adenine in Aqueous Hydrochloric Acid, Aqueous Sodium Hydroxide, Methanol, and Ethanol
}

\author{
Marthada V. Kilday \\ Center for Thermodynamics and Molecular Science, National Bureau of Standards, Washington, DC 20234 \\ January 3, 1979

\begin{abstract}
The following values were obtained from measurements of the enthalpy of solution of a well characterized sample of crystalline adenine in various solvents:

\begin{tabular}{|c|c|c|c|}
\hline Solvent & & $\Delta \mathrm{H}(\infty, 298.15 \mathrm{~K}) / \mathrm{kJ} \cdot \mathrm{mol}^{-1}$ & $\Delta C_{p} / \mathrm{J} \cdot \mathrm{mol}^{-1} \cdot \mathrm{K}^{-1}$ \\
\hline $\operatorname{HCl}(\mathrm{aq})$ & $\begin{array}{l}\text { lst protonation } \\
\text { 2nd protonation }\end{array}$ & $\begin{array}{l}11.41 \pm 0.18 \\
19.3 \pm 4.4\end{array}$ & $107 \pm 3^{*}\left(\right.$ at $\left.1 \mathrm{~mol} \mathrm{HCl} \cdot \mathrm{L}^{-1}\right)$ \\
\hline $\mathrm{NaOH}(\mathrm{aq})$ & $\begin{array}{l}\text { 1st proton dissociation } \\
2 \text { nd proton dissociation }\end{array}$ & $\begin{array}{l}15.21 \pm 0.06 \\
17.26 \pm 0.50\end{array}$ & $126 \pm 8 *\left(\right.$ at $\left.0.9 \mathrm{~mol} \mathrm{NaOH} \cdot \mathrm{L}^{-1}\right)$ \\
\hline $\begin{array}{l}\mathrm{CH}_{3} \mathrm{OH} \\
\mathrm{C}_{2} \mathrm{H}_{5} \mathrm{OH}\end{array}$ & & $\begin{array}{l}21.6 \pm 0.9^{*} \\
22.0 \pm 0.9^{*}\end{array}$ & $\begin{array}{c}93 \pm 14 \\
240 \pm 40^{*}\end{array}$ \\
\hline
\end{tabular}
\end{abstract}

$\begin{array}{lc} & \Delta H(\infty, 298.15 \mathrm{~K}) / \mathrm{kJ} \cdot \mathrm{mol}^{-1} \\ & -22.1 \pm 1.1 \\ \text { Addition of } 1 \text { proton } & -14.2 \pm 2.2 \\ & \\ \text { Removal of } 1 \text { proton } & 37.6 \pm 1.0 \\ \text { Removal of } 2 \text { protons } & 95.5 \pm 1.0\end{array}$

Keywords: Adenine; enthalpy of dissociation; enthalpy of protonation; enthalpy of reaction; enthalpy of solution; nucleic acid bases; solution calorimetry; thermochemistry.

\section{Introduction}

The preceding papers in this series $[1,2]^{1}$ described the results of measurements of the enthalpies of solution in water for some of the bases of the nucleic acids. In this work the enthalpies of solution or reaction of adenine (Ade), $\mathrm{C}_{5} \mathrm{H}_{5} \mathrm{~N}_{5}$ or 6-amino purine, in other solvents are reported.

Enthalpies of protonation and of proton dissociation of Ade have previously been obtained by various methods including titrations and spectrophotometry at various temperatures and calorimetric titrations [3]. However, the Ade samples used in the earlier work were not characterized as were the samples

\footnotetext{
${ }^{1}$ Figures in brackets indicate literature references at the end of this paper.
}

used in this work. We have measured enthalpies of reaction for Ade in aqueous $\mathrm{HCl}$ and in aqueous $\mathrm{NaOH}$. The concentration range for the $\mathrm{HCl}$ and $\mathrm{NaOH}$ was $0.1 \mathrm{~mol} \cdot \mathrm{L}^{-1}$ to more than $6 \mathrm{~mol} \cdot \mathrm{L}^{-1}$. At about $5(\mathrm{~mol} \mathrm{HCl}) \mathrm{L}^{-1}$ there was evidence of a second protonation of Ade; this was suggested by Albert and Brown [4] as occurring at $\mathrm{pH}<1$. At about $4(\mathrm{~mol} \mathrm{NaOH}) \mathrm{L}^{-1}$ evidence of a second proton dissociation of Ade was observed; this has not been previously reported.

Adenine was found to be less than half as soluble in ethanol $(\mathrm{EtOH})$ as in methanol $(\mathrm{MeOH})$. A concentration dependence of the enthalpy of solution was observed in the range of about 1 to $8 \mathrm{mmol}$ Ade $(\mathrm{kg} \mathrm{MeOH})^{-1}$.

Values for $\Delta C_{p}$ were determined for the reactions of Ade in each of the four solvents. 


\section{Materials, Apparatus, and Procedures}

The adenine sample, Ade 2, previously described in detail [1] was used as received from a commercial source for all experiments reported in this work except one with Ade 5b, a sample recrystallized from aqueous solution [1]. The volatile matter for Ade 2, determined previously and presumed to be $\mathrm{H}_{2} \mathrm{O}$, was $(0.15 \pm 0.10)$ mass per cent or $(1.1 \pm 0.7)$ mole per cent, and for Ade $5 \mathrm{~b},(0.40 \pm 0.05)$ mass per cent or (2.9 \pm 0.4$)$ mole per cent. No other impurities were identified. These materials were assumed to be of high purity since the values for the enthalpy of solution at infinite dilution agreed with each other and were the highest of the six samples compared.

The calorimetric solutions of aqueous $\mathrm{HCl}$ and $\mathrm{NaOH}$ were taken from stock solutions prepared by dilution of the concentrated solutions with distilled water. The concentrations of the $\mathrm{HCl}$ stock solutions were determined by titrations using analytical reagent grade $\mathrm{Na}_{2} \mathrm{CO}_{3}$ (dried $\mathrm{l}$ h at $548 \mathrm{~K}$ ), with bromphenol blue as an end-point indicator; the solutions were boiled to remove $\mathrm{CO}_{2}$ before adding the final portion of acid. Potassium acid phthalate, NBS Standard Reference Material No. 84 h, was used in titrations to determine the concentration of the $\mathrm{NaOH}$ stock solutions with phenolphthalein as the end-point indicator. $\mathrm{CO}_{2}$-free air was bubbled through the solutions during these titrations.

The platinum sample holder with interchangeable cylinders has been described [5]. In this work only the smallest cylinder, of $0.7-\mathrm{mL}$ capacity, was used. It was filled in the laboratory atmosphere controlled at $(295.6 \pm 0.5) \mathrm{K}$ and $(30$ \pm 10 ) per cent relative humidity.

The platinum-lined adiabatic solution calorimeter, the measurement procedures, and the methods of calculation have been previously described $[5,6]$. The physical constants and calibrations were the same as those given in [1]. The experiments reported here were made intermittently during the period from April 1974 through May 1976. Most of these reactions were endothermic except those in solutions above $2(\mathrm{~mol} \mathrm{HCl}) \mathrm{L}^{-1}$ which were exothermic. Electrical energy was not added during the endothermic reactions (except as noted in one experiment) to prevent a decrease in the calorimeter temperature, because the energy absorbed was always less than $50 \mathrm{~J}$ and the decrease in the calorimeter temperature was less than $0.04 \mathrm{~K}$; thus, heat transfer corrections were usually negligible.

\section{Solution of Adenine in Aqueous $\mathrm{HCl}$}

The enthalpy of solution of adenine was measured in 24 experiments over the concentration range of 0.1 to 6.6 ( $\mathrm{mol}$ $\mathrm{HCl}) \mathrm{L}^{-1}$. The results obtained in these experiments are given in table 1. The column headings are defined as follows:
Expt. No. is a serial number for experiments with this calorimeter and indicates the chronological order of the experiments.

Mass of Ade has been corrected for the $\mathrm{H}_{2} \mathrm{O}$ in the samples; all weighings were corrected to vacuum.

Mass and Concentration of aqueous $\mathrm{HCl}$ solutions used as the calorimetric solutions are given.

$T_{\text {reaction }}$ is the mean temperature of reaction.

Reaction period is the elapsed time between the initiation of the reaction and the beginning of the rating period which follows the reaction.

Cal. Unc., the estimated calorimetric uncertainty for an experiment, is based on the duration of the reaction, the magnitude of the temperature change from the reaction, and the standard deviation of the slope of the rating period following the reaction (see [1] for details).

Electrical energy equivalents of the initial and final systems, $\epsilon_{i}$ and $\epsilon_{f}$, are given.

$\Delta T_{\text {reaction }}$ is the corrected temperature change for the reaction (see [5]).

$Q_{\text {reaction }}$ is the heat of the solution reaction represented by the following equation:

$$
Q_{\text {reaction }}=\Delta T_{\text {reaction }}\left(\frac{\epsilon_{i}+\epsilon_{f}}{2}\right)-q_{\text {vap }}
$$

where $q_{\text {vap }}$ is the heat of vaporization of the solution into the air space in the sample holder upon opening and

$$
q_{\text {vap }}=\Delta H_{\text {vap }}\left(V-\frac{s}{d}\right)(1-R H)
$$

where $\Delta H_{\text {vap }}$ is the enthalpy of vaporization of the solution per unit volume at the mean temperature of reaction, $V$ is the internal volume of the sample holder, $s$ is the mass of sample, $d$ is the density of the sample (for Ade, $d$ $\left.=1.47 \mathrm{~g} \cdot \mathrm{mL}^{-1}[1]\right)$, and $R H$ is the relative humidity of the atmosphere in which the sample was transferred to the sample holder.

$\Delta H_{m}(T)$ is the enthalpy of solution at the temperature and concentration of the measurement, and

$$
\Delta H_{m}(T)=-Q_{\text {reaction }} \cdot M(\text { Mass of Ade })^{-1}
$$

where $M$ is the molecular mass of adenine.

Corr. to $T=298.15 \mathrm{~K}$ is $\Delta C_{p}\left(T_{\text {reaction }}-298.15 \mathrm{~K}\right)$ where $\Delta C_{p}$ is the thermal coefficient determined for the reaction.

$\Delta H_{m}(298.15 \mathrm{~K})$ is the enthalpy of solution at the standard temperature or $\Delta H_{m}(T)+$ (Corr. to $\left.T=298.15 \mathrm{~K}\right)$.

The value used for $\Delta C_{p}, 107 \mathrm{~J} \cdot \mathrm{mol}^{-1} \cdot \mathrm{K}^{-1}$, was calculated from Expt. Nos. 953 and 954 in which the $\mathrm{HCl}$ concentration was approximately $1 \mathrm{~mol} \cdot \mathrm{L}^{-1}$. The uncertainty in the $\Delta C_{p}$ value is estimated to be 2.5 per cent or 3 
Table 1. Data from the measurements of the enthalpy of solution of adenine in aqueous HC1.

\begin{tabular}{|c|c|c|c|c|c|c|c|c|c|c|c|c|c|}
\hline \multirow{2}{*}{$\begin{array}{c}\text { Expt. } \\
\text { No. }\end{array}$} & \multirow{2}{*}{$\begin{array}{c}\text { Mass of } \\
\text { Ade }\end{array}$} & \multicolumn{2}{|c|}{ HCl Soln. } & \multirow{2}{*}{${ }^{\mathrm{T}}$ reaction } & \multirow{2}{*}{$\begin{array}{c}\text { Reaction } \\
\text { period }\end{array}$} & \multirow{2}{*}{$\begin{array}{l}\text { Cal. } \\
\text { unc. }\end{array}$} & \multicolumn{2}{|c|}{$\begin{array}{c}\text { Electrical energy } \\
\text { equivalent }\end{array}$} & \multirow{2}{*}{$\Delta T$ reaction } & \multirow{2}{*}{${ }^{\text {Qreaction }}{ }^{\mathrm{b}}$} & \multirow{2}{*}{$\Delta \mathrm{H}_{\mathrm{m}}(\mathrm{T})$} & \multirow{2}{*}{$\begin{array}{c}\text { Corr. to } \\
\mathrm{T}= \\
298.15 \mathrm{~K}\end{array}$} & \multirow{2}{*}{$\Delta \mathrm{Hi}_{\mathrm{m}}(298.15 \mathrm{~K})$} \\
\hline & & Mass & Conc. & & & & Initial & Final & & & & & \\
\hline & $\mathrm{g}$ & $\mathrm{g}$ & $\mathrm{mol} / \mathrm{L}$ & K & $\min$ & $\%$ & \multicolumn{2}{|c|}{$\mathrm{J} / \mathrm{K}$} & K & $\mathrm{J}$ & $\mathrm{J} / \mathrm{mol}$ & $\mathrm{J} / \mathrm{mol}$ & $\mathrm{J} / \mathrm{mol}$ \\
\hline 946 & 0.19909 & 302.474 & 0.101 & 298.078 & 13 & p. 34 & 1728.45 & 1727.70 & -0.009179 & -15.84 & 10751 & -8 & 10759 \\
\hline 952 & .19719 & 302.334 & .102 & 298.106 & 48 & .77 & 1727.87 & 1727.50 & -.009272 & -16.00 & 10964 & -5 & 10969 \\
\hline 947 & .24470 & 302.433 & .787 & 298.171 & 18 & .89 & 1676.33 & 1674.13 & -.007609 & -12.73 & 7030 & 3 & 7027 \\
\hline 948 & .22705 & 302.418 & .787 & 298.173 & 28 & .95 & 1677.25 & 1676.86 & -.007355 & $-12 \cdot 31$ & 7326 & 2 & 7324 \\
\hline 953 & .19566 & 307.388 & .997 & 298.146 & 38 & .98 & 1680.58 & 1680.14 & -.005449 & -9.14 & 6312 & 0 & 6312 \\
\hline 954 & .19632 & 307.148 & .997 & 308.920 & 8 & .28 & 1682.08 & 1681.79 & -.006467 & -10.84 & 7461 & 1148 & 6313 \\
\hline 955 & .20432 & 307.330 & 1.980 & 298.206 & 48 & 6.06 & 1612.30 & 1612.33 & -.001271 & -2.03 & 1342 & 6 & 1336 \\
\hline 951 & .20782 & 307.319 & 2.946 & 298.306 & 48 & 1.63 & 1549.82 & 1550.14 & .003639 & 5.66 & -3680 & 17 & -3697 \\
\hline 1007 & .19610 & 308.782 & 3.509 & 298.141 & 38 & p. 85 & 1522.78 & 1522.33 & .006465 & 9.86 & -6794 & -1 & -6793 \\
\hline 1127 & .19740 & 324.186 & 3.851 & 298.174 & 33 & .51 & 1549.86 & 1550.19 & .008101 & 12.58 & -8612 & 3 & -8615 \\
\hline 956 & .19548 & 307.262 & 3.944 & 298.316 & 33 & .45 & 1492.95 & 1493.51 & .009012 & 13.48 & -9318 & 18 & -9336 \\
\hline 1008 & .19975 & 322.778 & 3.991 & 298.140 & 38 & .75 & 1542.28 & 1542.08 & .009064 & 14.00 & -9471 & 1 & -9470 \\
\hline 1128 & .21586 & 325.470 & 4.194 & 298.188 & 28 & .38 & 1537.04 & 1537.11 & .010526 & 16.20 & -10141 & 4 & -10145 \\
\hline 1130 & .18850 & 328.966 & 4.809 & 298.186 & 43 & .42 & 1515.54 & 1515.37 & .012540 & 19.02 & -13620 & 4 & -13624 \\
\hline
\end{tabular}

SECOND PROTONATION

\begin{tabular}{|c|c|c|c|c|c|c|c|c|c|c|c|c|c|}
\hline 1005 & .19524 & 307.460 & 5.130 & 298.194 & 78 & .66 & 1434.03 & 1433.89 & .015479 & 22.22 & -15379 & 5 & -15384 \\
\hline 1006 & .18931 & 307.425 & 5.130 & 298.246 & 58 & .49 & 1434.22 & 1434.02 & .015144 & 21.74 & -15518 & 10 & -15528 \\
\hline 1133 & .20607 & 331.755 & 5.401 & 298.210 & 68 & .42 & 1492.62 & 1493.90 & .017281 & 25.82 & -16931 & 6 & -16937 \\
\hline 1129 & .19074 & 332.711 & 5.592 & 298.216 & 88 & .48 & 1488.02 & 1487.90 & .016967 & 25.27 & -17902 & 7 & -17909 \\
\hline 1132 & .20291 & 333.994 & 5.794 & 298.208 & 83 & .48 & 1482.22 & 1482.33 & .019887 & 29.50 & -19646 & 6 & -19652 \\
\hline 1131 & .20011 & 334.339 & 6.026 & 298.213 & 128 & .64 & 1472.70 & 1472.78 & .021211 & 31.26 & -21109 & 7 & -21116 \\
\hline 949 & .18931 & 307.403 & 6.030 & 298.236 & 153 & .77 & 1393.46 & 1393.06 & .021849 & 30.46 & -21742 & 9 & -21751 \\
\hline 950 & .19844 & 307.308 & 6.030 & 298.198 & 104 & .53 & 1392.85 & 1392.78 & .023523 & 32.78 & -22322 & 5 & -22327 \\
\hline 1143 & .20026 & 332.273 & 6.632 & 298.278 & 103 & .81 & 1440.10 & 1440.13 & .026737 & 38.52 & -25992 & 14 & -26006 \\
\hline 1144 & .19234 & 332.269 & 6.632 & 298.285 & 113 & .72 & 1439.60 & 1439.78 & .024324 & 35.04 & -24617 & 15 & -24632 \\
\hline
\end{tabular}

${ }^{\mathrm{a}}$ Corrected for $\mathrm{H}_{2} \mathrm{O}$ in sample: Ade $5 \mathrm{~b}$ in No. $1005,(0.40 \pm 0.05)$ mass\%; Ade 2 in all others, (0.15 \pm 0.10$)$ mass\% - see [1].

$\mathrm{b}_{\mathrm{q}}=-0.04 \mathrm{~J}$ for No. 954 and $-0.02 \mathrm{~J}$ for all other experiments, was subtracted from the measured heat of reaction.

$\mathrm{J} \cdot \mathrm{mol}^{-1} \cdot \mathrm{K}^{-1}$ which is twice the sum of the estimated calorimetric uncertainties. At other concentrations the uncertainty may be somewhat greater.

The experiments given in table 1 are listed in order of increasing concentration of the $\mathrm{HCl}$ solutions. The adenine samples, $0.2 \mathrm{~g}$ or $0.0015 \mathrm{~mol}$, are Ade 2 except in Expt. No. 1005 where Ade 5b was used. In Expt. No. 954 at 308 K, $q_{\text {vap }}$ was estimated to be $-0.04 \mathrm{~J}$ and in the other experiments, $-0.02 \mathrm{~J}$. The data in table 1 show that the reactions are decreasingly endothermic up to about $2(\mathrm{~mol} \mathrm{HCl}) \mathrm{L}^{-1}$ after which they are increasingly exothermic. No undissolved material was observed in the final solutions.

In figure 1 are plotted the values from table 1 for $\Delta H_{m}$ (298.15 K) as a function of $\mathrm{HCl}$ concentration. No corrections were made in these experiments for the variations in adenine concentration, 1.4 to $1.8 \mathrm{mmol} \cdot \mathrm{kg}^{-1}$ solution. The adenine concentration dependence of the enthalpy of solution in water reported previously [1] was small with a large uncertainty. Examination of the values for $\Delta H_{m}(298.15 \mathrm{~K})$ in table 1 for those experiments where the same concentration of $\mathrm{HCl}$ solution was used revealed no consistent dependence on Ade concentration. It is assumed that the differences are due to sample inhomogeneity and experimental uncertainty.

The two straight lines shown in figure 1 were obtained by fitting linear equations to the data for $\Delta H_{m}(298.15 \mathrm{~K})$ and $\mathrm{HCl}$ concentration by the method of least squares, and may be represented by the following equations: for the 14 data points below $5(\mathrm{~mol} \mathrm{HCl}) \mathrm{L}^{-1}$, 


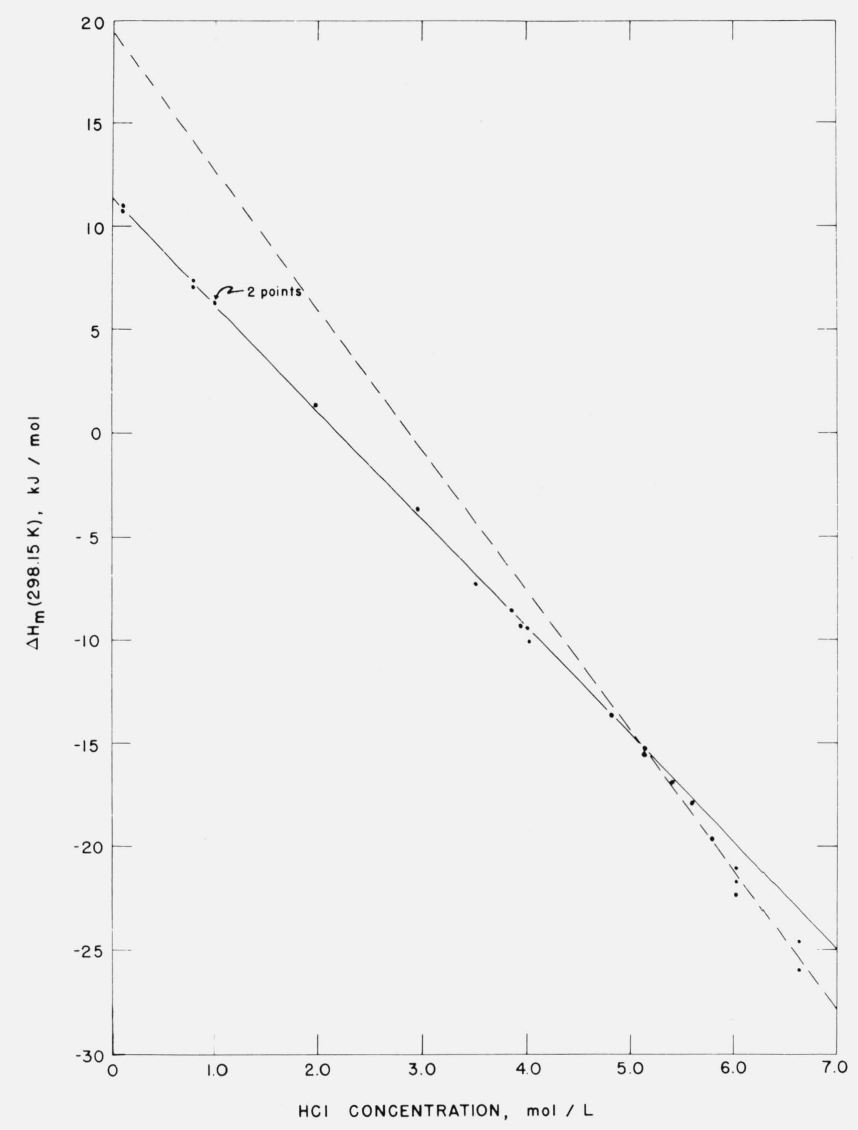

Figure 1. Plot showing the values for the enthalpy of solution of adenine at various concentrations of aqueous HCl solutions.

Least squares fits of linear equations to the data are represented by the solid line for the points at less than $5(\mathrm{~mol} \mathrm{HCl}) \mathrm{L}^{-1}$, and by the broken line for those at greater than $5(\mathrm{~mol} \mathrm{HCl}) \mathrm{L}^{-1}$. The change in slope is assumed to be the result of a second protonation of the adenine molecule.

$\Delta H_{m}(298.15 \mathrm{~K}), \mathrm{kJ} \cdot \mathrm{mol}^{-1}$

$$
=(11.411 \pm 0.080)-(5.194 \pm 0.028) C,
$$

and for the 10 data points above $5(\mathrm{~mol} \mathrm{HCl}) \mathrm{L}^{-1}$,

$\Delta H_{m}(298.15 \mathrm{~K}), \mathrm{kJ} \cdot \mathrm{mol}^{-1}$

$$
=(19.3 \pm 2.0)-(6.76 \pm 0.34) C,
$$

where $C$ is the concentration of $\mathrm{HCl}$ in $\mathrm{mol} \cdot \mathrm{L}^{-1}$ and the standard deviations of the fits are $0.17 \mathrm{~kJ} \cdot \mathrm{mol}^{-1}$ and 0.55 $\mathrm{kJ} \cdot \mathrm{mol}^{-1}$, respectively. The uncertainties are the standard deviations. From the difference in the two intercepts we obtain the enthalpy of the second protonation at infinite dilution, $(7.9 \pm 2.0) \mathrm{kJ} \cdot \mathrm{mol}^{-1}$. The change in slope at $5(\mathrm{~mol}$ HCL) $\mathrm{L}^{-1}$ is apparently the result of the second protonation previously reported by Albert and Brown [4] at $\mathrm{pH}<1$.

It should also be noted that the length of the reaction periods given in table 1 fall into three groups: $(30 \pm 18) \mathrm{min}$ for the first 14 experiments but omitting the one at $309 \mathrm{~K}$, $(73 \pm 15) \mathrm{min}$ for the next 5 experiments, and (128 \pm 25$)$ min for the last 5 experiments. This suggests a third protonation between 5.8 and $6.0(\mathrm{~mol} \mathrm{HCl}) \mathrm{L}^{-1}$; however, the uncertainties in the slopes and intercepts do not justify separation of the last two groups.

\section{Solution of Adenine in Aqueous $\mathrm{NaOH}$}

In table 2 are the data for 20 experiments in which the enthalpy of solution of Ade 2 in aqueous $\mathrm{NaOH}$ solutions was measured. The description of column headings given in section 3 also applies to table 2 . It is assumed that $q_{\text {vap }}$ is negligibly small in these experiments because if the solution were pure water $q_{\text {vap }}$ would be less than $0.05 \mathrm{~J}$ in the worst case (at $309 \mathrm{~K}$ ); the corrections are smaller than this since the vapor pressure of the $\mathrm{NaOH}$ solution is less than that of water. 
Table 2. Data from the measurements of the enthalpy of solution of adenine in aqueous $\mathrm{NaOH}$.

\begin{tabular}{|c|c|c|c|c|c|c|c|c|c|c|c|c|c|}
\hline \multirow{2}{*}{$\begin{array}{l}\text { Expt. } \\
\text { No. }\end{array}$} & \multirow{2}{*}{$\begin{array}{l}\text { Mass of } \\
\text { Ade }\end{array}$} & \multicolumn{2}{|c|}{ INaOH Soln. } & \multirow{2}{*}{$\mathrm{T}_{\text {reaction }}$} & \multirow{2}{*}{$\begin{array}{r}\text { Reaction } \\
\text { periodb }\end{array}$} & \multirow{2}{*}{$\begin{array}{l}\text { Cal. } \\
\text { unc. }\end{array}$} & \multicolumn{2}{|c|}{$\left[\begin{array}{c}\text { Electrical energy } \\
\text { equivalent }\end{array}\right.$} & \multirow{2}{*}{$-\Delta \mathrm{T}_{\text {reaction }}$} & \multirow{2}{*}{${ }^{-0}$ reaction } & \multirow{2}{*}{$\Delta H_{m}(T)$} & \multirow{2}{*}{$\begin{array}{c}\text { Corr. to } \\
\mathrm{T}= \\
298.15 \mathrm{~K}\end{array}$} & \multirow{2}{*}{$\Delta \mathrm{H}_{\mathrm{m}}(298.15 \mathrm{~K})$} \\
\hline & & Mass & Conc. & & & & Initial & Final & & & & & \\
\hline & g & $\mathrm{g}$ & $\mathrm{mol} / \mathrm{L}$ & K & $\min$ & $\%$ & \multicolumn{2}{|c|}{$\mathrm{J} / \mathrm{K}$} & $\mathrm{K}$ & $\mathrm{J}$ & $\mathrm{J} / \mathrm{mo} 1$ & $\mathrm{~J} / \mathrm{mol}$ & $\mathrm{J} / \mathrm{mol}$ \\
\hline 960 & 0.19889 & 307.371 & 0.0912 & 298.122 & 23 & 0.38 & 1750.23 & 1749.37 & 0.012727 & 22.27 & 15130 & -4 & 15134 \\
\hline 961 & .21312 & 307.416 & .0912 & 298.149 & 18 & .31 & 1750.59 & 1750.16 & .013790 & 24.14 & 15306 & 0 & 15306 \\
\hline 1134 & .19707 & 308.618 & .197 & 298.193 & 13 & .17 & 1744.30 & 1743.90 & .012696 & 22.14 & 15181 & 5 & 15176 \\
\hline 962 & .19380 & 307.363 & .462 & 298.127 & 13 & .28 & 1725.49 & 1725.71 & .012437 & 21.46 & 14963 & & 14966 \\
\hline 963 & .20732 & 307.378 & .462 & 298.128 & 18 & .29 & 1725.26 & 1724.71 & .013260 & 22.87 & 14906 & -3 & 14909 \\
\hline 1135 & .19241 & 308.571 & .545 & 298.193 & 13 & .21 & 1722.08 & 1721.82 & .012416 & 21.38 & 15015 & 5 & 15010 \\
\hline 957 & .19922 & 307.223 & .919 & 298.158 & 13 & .31 & 1699.37 & 1698.97 & .012974 & 22.04 & 14949 & 1 & 14948 \\
\hline 958 & .19357 & 307.204 & .919 & 309.270 & 13 & .17 & 1703.13 & 1703.74 & .013703 & 23.34 & 16293 & 1402 & 14891 \\
\hline 959 & .19976 & 307.259 & .919 & 298.159 & 18 & .16 & 1699.38 & 1699.58 & .012907 & 21.93 & 14834 & 1 & 14833 \\
\hline 1139 & .19726 & 325.979 & 1.998 & 298.105 & 13 & .26 & 1725.78 & 1726.20 & .012256 & 21.15 & 14488 & -6 & 14494 \\
\hline 1138 & .18930 & 335.734 & 3.012 & 298.102 & 13 & .34 & 1734.68 & 1734.78 & .011410 & 19.79 & 14127 & -6 & 14133 \\
\hline 1148 & .19732 & 345.010 & 3.582 & 298.101 & 13 & .20 & 1756.52 & 1756.62 & .011538 & 20.27 & 13881 & -6 & 13887 \\
\hline
\end{tabular}

SECOND DISSOCIATION

\begin{tabular}{|c|c|c|c|c|c|c|c|c|c|c|c|c|c|}
\hline 1140 & .19024 & 346.960 & 4.015 & 293.089 & 13 & .27 & 1755.71 & 1756.18 & .011058 & 19.42 & 13794 & $1-8$ & 13802 \\
\hline 1149 & .19448 & 350.243 & 4.096 & 298.116 & 13 & .32 & 1766.38 & 1766.76 & .011051 & 19.52 & 13563 & -4 & 13567 \\
\hline 1142 & .20667 & 348.501 & 4.221 & 298.111 & 18 & .22 & 1757.53 & 1757.96 & .011635 & 20.45 & 13371 & -5 & 13376 \\
\hline 1141 & .18986 & 353.112 & 4.498 & 298.092 & 12 & .28 & 1770.04 & 1770.62 & .010500 & 18.59 & 13231 & -7 & 13238 \\
\hline 1136 & .21816 & 313.451 & 5.064 & 298.475 & 8 & .20 & 1618.02 & 1618.14 & .012852 & 20.80 & 12883 & 41 & 12842 \\
\hline 1137 & .20246 & 333.433 & 5.064 & 298.113 & 13 & .23 & 1691.02 & 1691.34 & .011372 & 19.23 & 12835 & $1-5$ & 12840 \\
\hline 1145 & .19739 & 363.371 & 6.078 & 298.095 & 18 & .40 & 1786.83 & 1787.58 & .009697 & 17.33 & 11864 & -7 & 11871 \\
\hline 1147 & .19118 & 363.306 & 6.078 & 298.081 & 13 & .28 & 1787.33 & 1787.60 & .009320 & 16.66 & 11775 & -9 & 11784 \\
\hline
\end{tabular}

${ }^{\mathrm{a}}$ Corrected for $\mathrm{H}_{2} \mathrm{O}$ in sample: $(0.15 \pm 0.10)$ mass $\%$.

bhe stirring rate was $450 \mathrm{rpm}$ in Expts. No. 959, 960, 962 and 963; $550 \mathrm{rpm}$ in a11 other experiments.

The $\Delta C_{p}$ for the reaction, $126 \mathrm{~J} \cdot \mathrm{mol}^{-1} \cdot \mathrm{K}^{-1}$, was determined from the three experiments (No. 957-959) using 0.919 $(\mathrm{mol} \mathrm{NaOH}) \mathrm{L}^{-1}$; an estimated uncertainty of $8 \mathrm{~J} \cdot \mathrm{mol}^{-1} \cdot \mathrm{K}^{-1}$ was obtained from the sum of the estimated calorimetric uncertainties (table 2 ) divided by the temperature difference. The uncertainty may be greater at other concentrations.

From the lengths of the reaction periods given in table 2, it can be seen that all of the reactions were rapid. No undissolved material was visible in the final solutions. The value of the enthalpy of solution decreases as the concentration of the $\mathrm{NaOH}$ calorimetric solutions increases. Figure 2 is a plot of $\Delta H_{m}(298.15 \mathrm{~K})$ as a function of $\mathrm{NaOH}$ molarity. It shows a change of slope near $4(\mathrm{~mol} \mathrm{NaOH}) \mathrm{L}^{-1}$ which probably indicates a second proton dissociation not previously reported. The results of fitting linear equations to the data for $\Delta H_{m}(298.15 \mathrm{~K})$ and $\mathrm{NaOH}$ concentration from table 2 by the method of least squares are as follows: for 12 points at less than $4(\mathrm{~mol} \mathrm{NaOH}) \mathrm{L}^{-1}$,

$\Delta H_{m}(298.15 \mathrm{~K}), \mathrm{kJ} \cdot \mathrm{mol}^{-1}$

$$
=(15.207 \pm 0.029)-(0.364 \pm 0.019) C
$$

and for the 8 points at greater than $4(\mathrm{~mol} \mathrm{NaOH}) \mathrm{L}^{-1}$,

$\Delta H_{m}(298.15 \mathrm{~K}), \mathrm{kJ} \cdot \mathrm{mol}^{-1}$

$$
=(17.26 \pm 0.21)-(0.889 \pm 0.042) C
$$

where $C$ is the $\mathrm{NaOH}$ concentration in $\mathrm{mol} \cdot \mathrm{L}^{-1}$ and the uncertainties are the standard deviations. The standard deviations of the fits are $0.072 \mathrm{~kJ} \cdot \mathrm{mol}^{-1}$ and 0.093 $\mathrm{kJ} \cdot \mathrm{mol}^{-1}$, respectively. From the difference in the intercepts, we obtain the enthalpy of the second proton dissociation at infinite dilution, $(2.06 \pm 0.21) \mathrm{kJ} \cdot \mathrm{mol}^{-1}$. 


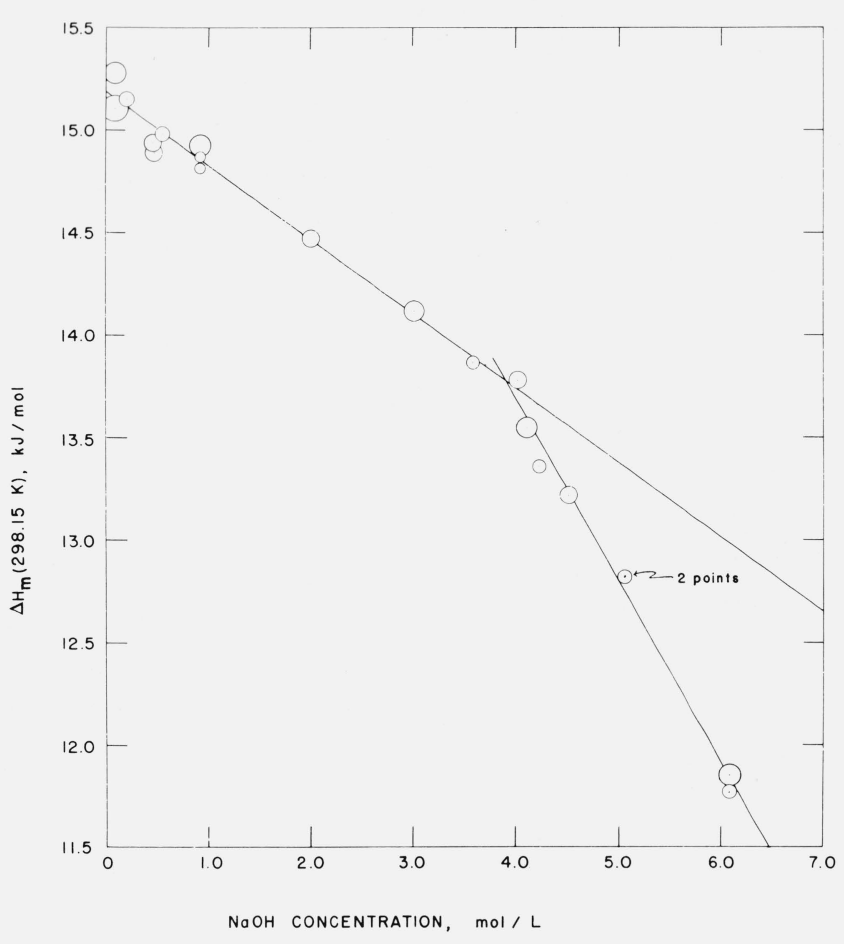

FIGURE 2. Plot showing the values for the enthalpy of solution of adenine at various concentrations of aqueous $\mathrm{NaOH}$ solutions.

The two lines shown were obtained by fitting linear equations to the data by the method of least squares. The change in slope at approximately $4(\mathrm{~mol} \mathrm{NaOH}) \mathrm{L}^{-1}$ is assumed to be the result of a second proton dissociation of the adenine molecule. The radius of a circle is equal to the estimated calorimetric uncertainty for the experiment (see text).

\section{Solution of Adenine in $\mathrm{MeOH}$ and in $\mathrm{EtOH}$}

The data are given in table 3 for 12 measurements of the enthalpy of solution of Ade 2 in ACS Spectro-grade methanol, and for 2 measurements in ACS absolute ethanol. The column headings described in section 3 also apply to table 3 .

The rating period slopes are given in table 3 because they differ markedly from those where the aqueous calorimetric solutions were used. The reaction period was preceded by the initial slope and followed by the final slope. These slopes are obtained by fitting a linear equation to about 20 timetemperature observations at 100 -s intervals by the method of least squares. At $298 \mathrm{~K}$, with a stirring rate of $550 \mathrm{rpm}$, the rating period slopes for the aqueous $\mathrm{HCl}$ solutions were between 6.5 and $7.5 \mu K \cdot s^{-1}$ and for the aqueous $\mathrm{NaOH}$ solutions, between 5.9 and $6.6 \mu K \cdot s^{-1}$; in both cases the final slope was 0.1 to $0.3 \mu K \cdot s^{-1}$ larger than the initial slope. For the solution reaction in methanol, the final slope was always more than $1 \mu \mathrm{K} \cdot s^{-1}$ smaller than the initial slope even with the variations in temperature and stirring rate. This indicates an increase in the evaporation cooling effect after the reaction which is surprising in view of the fact that non-volatile molecules were added to the methanol. The solutions apparently depart greatly from ideal behavior. For the solutions in ethanol, the initial and final slopes were essentially equal.

Some undissolved particles were visible at the bottom in all final solutions in the experiments with methanol and ethanol. The amounts appeared to be independent of both concentration and temperature of reaction. The undissolved material was not analyzed, but in one noncalorimetric experiment about $8 \mathrm{mg}$ or 4 per cent of the sample mass was recovered in a filter. Most of the final solutions were cloudy, but the cloudiness decreased as the reaction temperature increased; at about $342 \mathrm{~K}$, the final solutions were essentially clear. When a cloudy final solution was filtered through Whatman No. 50 hardened filter paper (for fine crystalline precipitates), the filtrate was clear indicating that the cloudiness was caused by finely divided material suspended in the solution. It is unlikely that the suspended material was adenine since its density is nearly twice that of the alcohols. The unreacted material was probably an impurity (or impurities) in the adenine which was soluble in water, but insoluble in the alcohols at the lower temperatures.

The $\Delta C_{p}$ for the reaction of Ade in methanol was obtained by fitting a linear equation by the least squares method to the data for $\Delta H_{m}(T)$ and $T_{\text {reaction }}$ for 10 experiments in table 3 (omitting Nos. 1009 and 1012 because the values for $\Delta H_{m}(T)$ were quite low and leakage of the sample holder was suspected). A plot of these data is shown in figure 3. The slope of the line is $\Delta C_{p}=(92.9 \pm 5.3) \mathrm{J} \cdot \mathrm{mol}^{-1} \cdot \mathrm{K}^{-1}$; the uncertainty given is the standard deviation and the standard deviation of the fit is $0.18 \mathrm{~kJ} \cdot \mathrm{mol}^{-1}$.

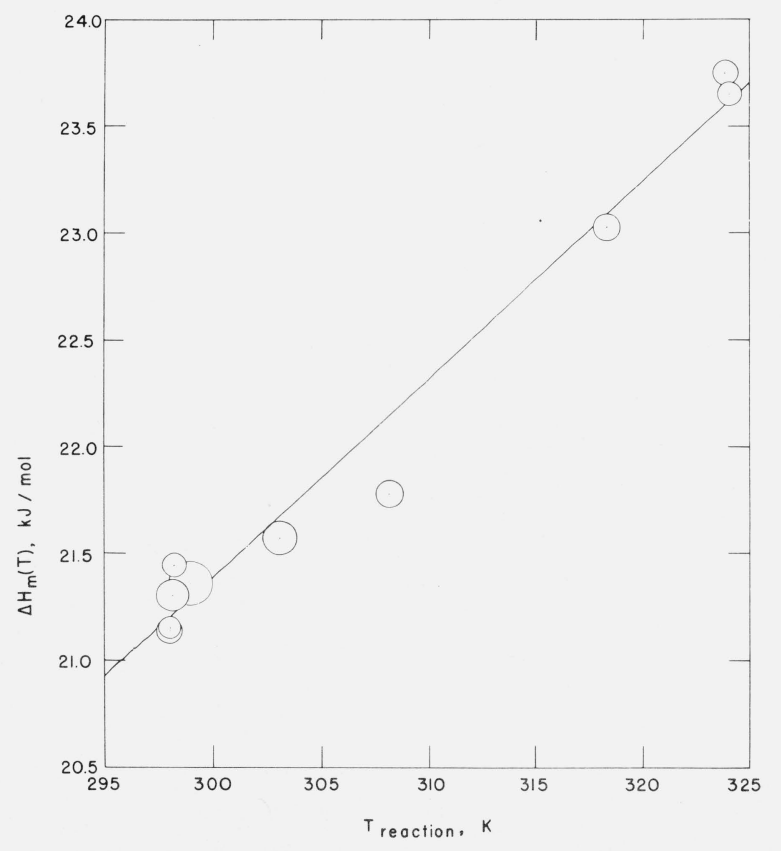

Figure 3. Plot showing the relationship between the enthalpy of solution of adenine in methanol and the temperature of reaction.

The straight line shown represents the result of fitting a linear equation to the data. The slope of the line, $\Delta C_{p}$, is $(92.9 \pm 5.3) \mathrm{J} \cdot \mathrm{mol}^{-1} \cdot \mathrm{K}^{-1}$. The radius of a circle is equal to the estimated calorimetric uncertainty for the experiment (see text). 
Tajle 3. Data from measurements of the enthalpies of solution of adenine in methanol and in ethanol.

\begin{tabular}{|c|c|c|c|c|c|c|c|c|c|c|c|c|c|c|c|c|c|c|}
\hline $\begin{array}{l}\text { Expt. } \\
\text { No. }\end{array}$ & \multicolumn{2}{|c|}{ Mass } & $\begin{array}{l}\text { Fina1 } \\
\text { Ade } \\
\text { conc. }\end{array}$ & \multicolumn{2}{|c|}{$\begin{array}{l}\text { Rating period } \\
\text { slopes }\end{array}$} & ${ }^{\mathrm{T}}$ reaction & $\begin{array}{c}\text { Reaction } \\
\text { period }\end{array}$ & $\begin{array}{l}\text { Cal. } \\
\text { unc. }\end{array}$ & \multicolumn{2}{|c|}{\begin{tabular}{|c|}
$\begin{array}{c}\text { Electrical energy } \\
\text { equivalent }\end{array}$ \\
Initial Final
\end{tabular}} & $-\Delta \mathrm{T}_{\text {reaction }}$ & $\mathrm{q}_{\text {vap }}$ & ${ }^{-Q}$ reaction & $\Delta \mathrm{H}_{\mathrm{m}}(\mathrm{T})$ & $\begin{array}{c}\text { Corr. to } \\
T= \\
298.15 \mathrm{k}\end{array}$ & $\Delta \mathrm{H}_{\mathrm{m}}(298.15 \mathrm{~K})$ & $\begin{array}{c}\text { Corr. to } \\
\text { infinite } \\
\text { diln. }\end{array}$ & $\Delta \mathrm{H}_{\infty}(298.15 \mathrm{~K})$ \\
\hline & $\mathrm{g}$ & $\mathrm{g}$ & $\mathrm{mmo1} / \mathrm{kg}$ & $\frac{1}{4 K}$ & & $\mathrm{~K}$ & $\min$ & $\%$ & & $/ \mathrm{K}$ & K & $\mathrm{J}$ & $\mathrm{J}$ & $\mathrm{J} / \mathrm{mol}$ & $\mathrm{J} / \mathrm{mol}$ & $\mathrm{J} / \mathrm{mol}$ & $-\mathrm{J} / \mathrm{mol}$ & $\mathrm{J} / \mathrm{mo} 1$ \\
\hline \multicolumn{19}{|c|}{ Solvent: Spectro ACS Hethano1 } \\
\hline 966 & 0.09183 & 242.003 & 2.8081 & 8.2 & 7.1 & 298.123 & 38 & 0.35 & 1086.99 & 1086.83 & 0.013508 & 0.18 & 14.50 & 21337 & 2 & 21339 & 319 & 21658 \\
\hline 967 & .05760 & 242.018 & 1.7613 & 8.0 & 6.7 & 298.973 & 48 & 1.06 & 1085.95 & 1086.59 & .008568 & .18 & 9.12 & 21395 & -76 & 21319 & 200 & 21519 \\
\hline 969 & .09479 & 237.012 & 2.9596 & 12.4 & 6.3 & 318.347 & 13 & 0.24 & 1104.19 & 1107.56 & .015023 & .44 & 16.18 & 23065 & -1876 & 21189 & 336 & 21526 \\
\hline 970 & .09616 & 237.057 & 3.0019 & 10.4 & 6.7 & 308.183 & 23 & .25 & 1089.34 & 1089.52 & .014500 & .28 & 15.52 & 21809 & -932 & 20877 & 341 & 21218 \\
\hline 1009 & .20832 & 237.047 & 6.5035 & 27.1 & 13.0 & 298.238 & 53 & .23 & 1069.34 & 1071.79 & .029624 & .16 & $\mathrm{e}_{31.59}$ & 20491 & 36 & 20527 & 739 & 21266 \\
\hline 1010 & .19218 & 237.062 & 5.9993 & 15.0 & 12.6 & 298.013 & 43 & .30 & 1072.09 & 1072.93 & d. .028238 & .16 & 30.12 & 21178 & -13 & 21165 & 682 & 21847 \\
\hline 1011 & .20450 & 237.072 & 6.3836 & 14.0 & 12.8 & 298.007 & 38 & .24 & 1072.03 & 1072.29 & .030026 & .16 & $e_{32.06}$ & 21184 & -13 & 21171 & 726 & 21897 \\
\hline 1012 & .27306 & 237.047 & 8.5247 & 13.8 & 12.5 & $c_{297.981}$ & 48 & .27 & 1072.01 & $(1062.70)$ & .038458 & .14 & $\mathrm{e}_{41.16}$ & 20368 & 16 & 20384 & 969 & 21353 \\
\hline 1013 & .14836 & 237.396 & 4.6248 & 13.8 & 12.8 & 298.117 & 38 & .22 & 1072.31 & 1072.31 & .022153 & .17 & 23.58 & 21477 & -3 & 21474 & 526 & 22000 \\
\hline 1014 & .09844 & 237.092 & 3.0726 & 8.5 & 6.2 & 303.101 & 38 & .34 & 1079.76 & 1079.72 & .014779 & .22 & 15.74 & 21606 & -460 & 21146 & 349 & 21495 \\
\hline 1015 & .10322 & 237.047 & 3.2224 & 9.4 & 4.7 & 323.820 & 23 & .21 & 1114.53 & 1118.34 & .016751 & .53 & 18.17 & 23787 & -2385 & 21402 & 366 & 21768 \\
\hline 1016 & .10153 & 237.047 & 3.1697 & 8.4 & 4.8 & 324.032 & 13 & .20 & $\mid 1115.84$ & $|1119.12|$ & .016422 & .55 & 17.80 & 23690 & -2404 & 21286 & 360 & 21646 \\
\hline
\end{tabular}

Solvent: Absolute Ethanol (ACS)

\begin{tabular}{l|l|l|l|l|l|l|l|l|l|l|l|l|l|l|l|l|l|l|}
1019 & 0.05061 & 236.771 & 1.5818 & 5.9 & 5.8 & 298.143 & 24 & 0.87 & 1048.20 & 1049.53 & 0.007949 & 0.10 & 8.24 & 22001 & ---- & 22000 \\
1020 & .09757 & 236.836 & 3.0488 & 4.9 & 5.0 & 311.164 & 33 & .60 & 1077.26 & 1078.62 & .017030 & .18 & 18.18 & 25178 &
\end{tabular}

${ }^{\mathrm{a}}$ Corrected for $\mathrm{H}_{2} \mathrm{O}$ in sample: $(0.15 \pm 0.10)$ mass\%.

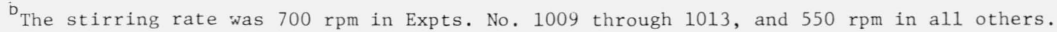

${ }^{c}$ Refers to the final temperature of the reaction since only the initial energy equivalent was used in calculating the heat of the reaction; all other experinents refer to the mean temperature of the reaction, and the mean energy equivalent was used.

$\mathrm{d}_{\text {Electrical energy }}(887.961 \mathrm{~J}$ ) was added during this reaction; the net $\Delta \mathrm{T}=0.799691 \mathrm{~K}$.

${ }^{e}$ Corrections for cepartures of the adiabatic shield from the calorimeter temperature: №. $1009=0.034 \mathrm{~J}$, №. $1011=0.027 \mathrm{~J}$, and No. $1012=0.070 \mathrm{~J}$. 
Figure 4 is a plot of the adenine concentration in the final solutions versus $\Delta H_{m}(298.15 \mathrm{~K})$ before the corrections to the mass of Ade for $\mathrm{H}_{2} \mathrm{O}$ in the sample were applied. These corrections were small and caused the line shown in figure 4 to be raised $0.02 \mathrm{~kJ} \cdot \mathrm{mol}^{-1}$ with a negligible change in slope. This line was obtained by fitting a linear equation to the data from the 12 experiments by the method of least squares. For the data which includes the $\mathrm{H}_{2} \mathrm{O}$ corrections,

$\Delta H_{m}(298.15 \mathrm{~K}), \mathrm{kJ} \cdot \mathrm{mol}^{-1}$

$$
=(21.60 \pm 0.18)-(0.114 \pm 0.038) C
$$

where $C$ is the Ade concentration in $\mathrm{mmol}(\mathrm{kg} \mathrm{MeOH})^{-1}$ and the uncertainties are standard deviations. The standard deviation of the fit is $0.26 \mathrm{~kJ} \cdot \mathrm{mol}^{-1}$. The slope, 113.7 $\mathrm{J} \cdot \mathrm{mol}^{-1} \cdot C^{-1}$ was used for the corrections to infinite dilution (table 3) which were added to $\Delta H_{m}(298.15 \mathrm{~K})$ to obtain $\Delta H(\infty, 298.15 \mathrm{~K})=(21.6 \pm 0.9) \mathrm{kJ} \cdot \mathrm{mol}^{-1}$; the large uncertainty of 4 per cent was assigned to account for the unidentified, undissolved material in the final solutions.
No corrections were made for the dilution in $\mathrm{MeOH}$ of the $\mathrm{H}_{2} \mathrm{O}$ impurity in the Ade primarily because of the uncertainty in the state of the $\mathrm{H}_{2} \mathrm{O}$. In the worst case (Expt. No. 1012) assuming liquid $\mathrm{H}_{2} \mathrm{O}$ in the Ade, the correction to $\Delta H(\infty$, $298.15 \mathrm{~K}$ ) would be less than $0.1 \mathrm{~kJ} \cdot \mathrm{mol}^{-1}$ which is much smaller than the assigned uncertainty.

In Expts. No. 1009, 1011, and 1012 (table 3), the heat of the endothermic reaction was large enough to result in small departures of the temperature of the adiabatic shield from that of the reaction vessel. Therefore small corrections for heat transfer from the shield to the vessel were made as previously described [5]. The need for this correction was eliminated in Expt. No. 1010 because precisely measured electrical energy was added during the reaction to prevent a decrease in the temperature of the reaction vessel.

In figure 4 , the experiments represented by the two points at the lower right (Expts. No. 1009 and 1012) were suspected of prereaction although the rating period slopes did not support this suspicion. If these two experiments are in error, we would conclude that the enthalpy of solution was independent of concentration in the range of these measurements.

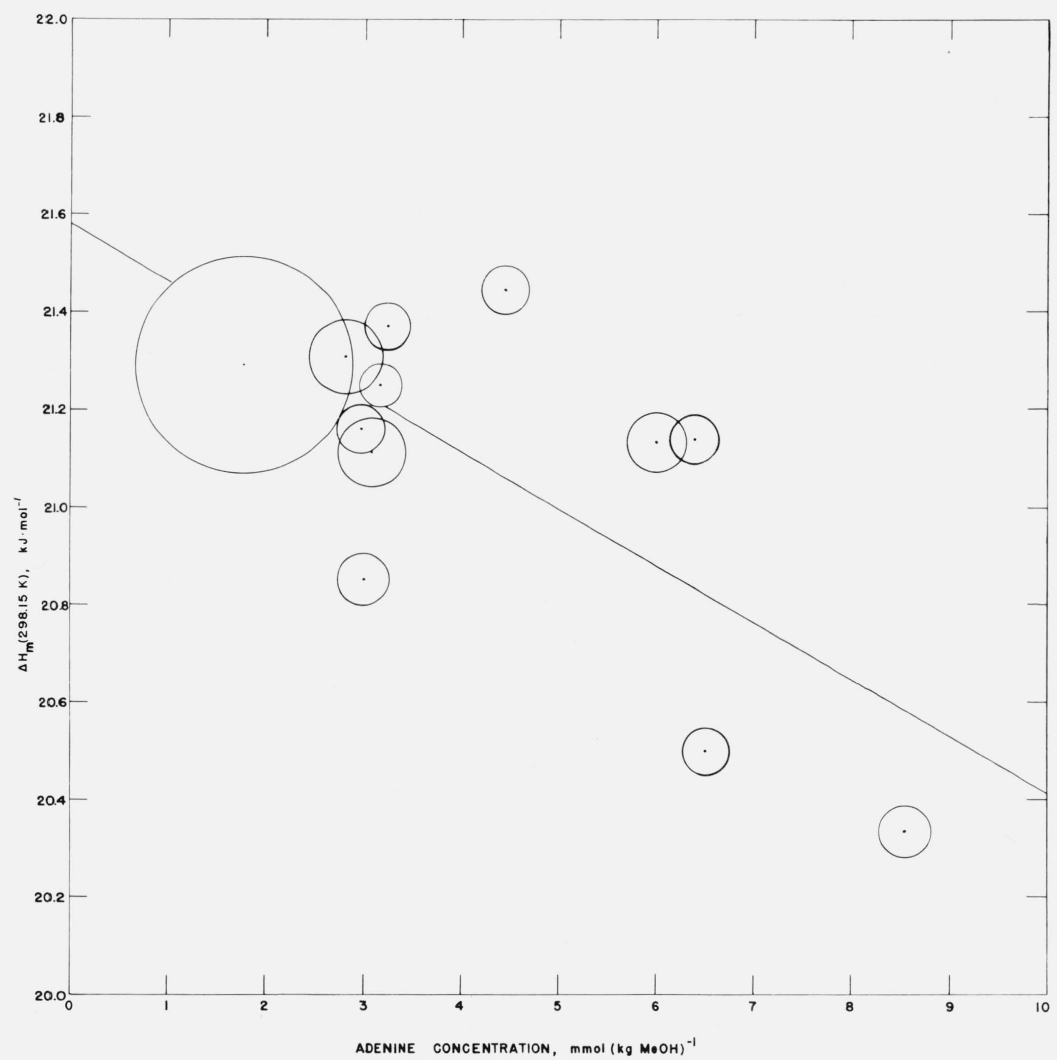

Figure 4. Plot showing the values for the enthalpy of solution of adenine in methanol at various concentrations of adenine.

The radius of a circle is equal to the estimated calorimetric uncertainty of the experiment (see text). The straight line shown is obtained by fitting a linear equation to the data by the least squares method; the slope is $(114+38) \mathrm{J} \cdot \mathrm{mol}^{-1}(\mathrm{mmol} \mathrm{Ade})^{-1}$ $(\mathrm{kg} \mathrm{MeOH})$. 
In preliminary experiments, it was learned that only about one-third as much Ade could be dissolved in ethanol as in an equal volume of methanol. The final solution in Expt. No. 1020 (table 3) was very close to saturation. At such low concentrations, meaningful dilution data were not obtained. However, $\Delta C_{p}$ for the reaction was about $(0.24 \pm 0.04)$ $\mathrm{kJ} \cdot \mathrm{mol}^{-1} \cdot \mathrm{K}^{-1}$ and $\Delta H(298.15 \mathrm{~K})=(22.0 \pm 0.9) \mathrm{kJ} \cdot \mathrm{mol}^{-1}$; the uncertainties are estimated taking into consideration the unreacted material in the final solutions.

\section{Discussion and Summary}

The structure of adenine has been given as follows [4]:

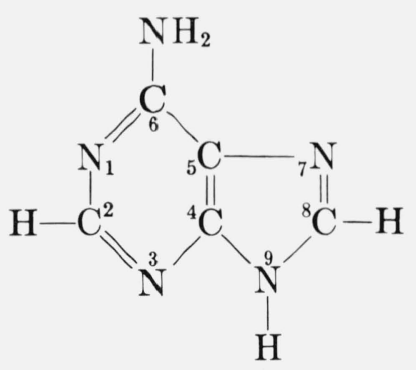

There are three possible sites for protonation at N1, N3, and $\mathrm{N} 7$, and two sites for proton dissociation at N9 and the amino group. A review [3] lists measurements of the enthalpy of protonation at $\mathrm{N} 1(\mathrm{pH} 4)$ and suggests a second protonation [4] at $\mathrm{N} 7(\mathrm{pH}<1)$; enthalpies of proton dissociation at $\mathrm{N9}$ $(\mathrm{pH} \mathrm{10)}$ are also listed.

The first work in this series [1] gave our best value for the enthalpy of solution at infinite dilution which may be represented by the following equation (where adenine = $\mathrm{H}_{2}$ Ade):

$$
\begin{aligned}
\mathrm{H}_{2} \operatorname{Ade}(\mathrm{c})+(\mathrm{aq}) & =\mathrm{H}_{2} \operatorname{Ade}(\mathrm{aq}), \\
\Delta H(\infty, 298.15 \mathrm{~K}) & =(33.47 \pm 1.00) \mathrm{kJ} \cdot \mathrm{mol}^{-1}
\end{aligned}
$$

From the measurements reported in section 3 of this work we assume the following equations:

$$
\begin{aligned}
\mathrm{H}_{2} \operatorname{Ade}(\mathrm{c})+\mathrm{H}^{+}(\mathrm{aq}) & =\mathrm{H}_{3} \operatorname{Ade}^{+}(\mathrm{aq}), \\
\Delta H(\infty, 298.15 \mathrm{~K}) & =(11.41 \pm 0.08) \mathrm{kJ} \cdot \mathrm{mol}^{-1} \\
\mathrm{H}_{2} \operatorname{Ade}(\mathrm{c})+2 \mathrm{H}^{+}(\mathrm{aq}) & =\mathrm{H}_{4} \operatorname{Ade}^{2+}(\mathrm{aq}), \\
\Delta H(\infty, 298.15 \mathrm{~K}) & =(19.3 \pm 2.0) \mathrm{kJ} \cdot \mathrm{mol}^{-1}
\end{aligned}
$$

(Some evidence is mentioned in section 3 that eq (3) may represent a triple protonation rather than the addition of the two protons as indicated here.) From the measurements in section 4 ,

$$
\begin{aligned}
\mathrm{H}_{2} \operatorname{Ade}(\mathrm{c})+\mathrm{OH}^{-}(\mathrm{aq}) & =\operatorname{HAde}^{-}(\mathrm{aq})+\mathrm{H}_{2} \mathrm{O}(l) \\
\Delta H(\infty, 298.15 \mathrm{~K}) & =(15.207 \pm 0.029) \mathrm{kJ} \cdot \mathrm{mol}^{-1} \\
\mathrm{H}_{2} \operatorname{Ade}(\mathrm{c})+2 \mathrm{OH}^{-}(\mathrm{aq}) & =\operatorname{Ade}^{2-}(\mathrm{aq})+2 \mathrm{H}_{2} \mathrm{O}(l) \\
\Delta H(\infty, 298.15 \mathrm{~K}) & =(17.26 \pm 0.21) \mathrm{kJ} \cdot \mathrm{mol}^{-1}
\end{aligned}
$$

By subtracting eq (1) from eq (2) and from eq (3) we obtain

$$
\begin{aligned}
\mathrm{H}_{2} \text { Ade }(\mathrm{aq})+\mathrm{H}^{+}(\mathrm{aq}) & =\mathrm{H}_{3} \operatorname{Ade}^{+}(\mathrm{aq}), \\
\Delta H(\infty, 298.15 \mathrm{~K}) & =-(22.1 \pm 1.0) \mathrm{kJ} \cdot \mathrm{mol}^{-1} \\
\mathrm{H}_{2} \operatorname{Ade}(\mathrm{aq})+2 \mathrm{H}^{+}(\mathrm{aq}) & =\mathrm{H}_{4} \mathrm{Ade}^{2+}(\mathrm{aq}), \\
\Delta H(\infty, 298.15 \mathrm{~K}) & =-(14.2 \pm 2.2) \mathrm{kJ} \cdot \mathrm{mol}^{-1}
\end{aligned}
$$

where the uncertainties are the square root of the sum of the squares of the individual uncertainties.

Equation (6) is equivalent to the protonation of $\mathrm{Nl}$ as given in [3]. The value obtained for this reaction by Christensen et al. using calorimetric titrations is $-(20.12 \pm 0.08)$ $\mathrm{kJ} \cdot \mathrm{mol}^{-1}[7]$; the purity of their sample was not determined. Equation (7) has not been previously measured although evidence for it was given by Albert and Brown [4].

Parker [8] has selected a "best" value for $\Delta H_{\mathrm{N}}{ }^{0}$ which may be represented by the equation,

$$
\begin{aligned}
\mathrm{H}^{+}+\mathrm{OH}^{-} & =\mathrm{H}_{2} \mathrm{O}(l), \\
\Delta H(\infty, 298.15 \mathrm{~K}) & =-55.84 \pm 0.10 \mathrm{~kJ} \cdot \mathrm{mol}^{-1}
\end{aligned}
$$

If the sum of eq (1) and eq (8) is subtracted from eq (4), we obtain

$$
\begin{gathered}
\mathrm{H}_{2} \operatorname{Ade}(\mathrm{aq})=\operatorname{HAde}^{-}(\mathrm{aq})+\mathrm{H}^{+}, \\
\Delta H(\infty, 298.15 \mathrm{~K})=(37.58 \pm 1.00) \mathrm{kJ} \cdot \mathrm{mol}^{-1}
\end{gathered}
$$

which is equivalent to the value, $(40.38 \pm 0.21) \mathrm{kJ} \cdot \mathrm{mol}^{-1}$, reported for the dissociation of the N9 proton by Christensen et al [7] using a sample of unknown purity. Similarly, if the sum of eq (1) and twice eq (8) is subtracted from eq (5) we obtain

$$
\begin{gathered}
\mathrm{H}_{2} \operatorname{Ade}(\mathrm{aq})=\operatorname{Ade}^{2-}(\mathrm{aq})+2 \mathrm{H}^{+}, \\
\Delta H(\infty, 298.15 \mathrm{~K})=(95.47 \pm 1.04) \mathrm{kJ} \cdot \mathrm{mol}^{-1}
\end{gathered}
$$

This reaction has not been previously reported and is assumed to be the proton dissociations at the amino group and N9.

Scruggs, Achter, and Ross [9] measured the solubility of adenine in methanol at $277.8 \mathrm{~K}$ and $309.8 \mathrm{~K}$. Assuming linearity between these temperatures, and the density of 
methanol $=0.79 \mathrm{~g} \cdot \mathrm{mL}^{-1}$, we calculate $8.0 \mathrm{mmol}$ Ade $(\mathrm{kg}$ $\mathrm{MeOH})^{-1}$ for the saturated solution. (This is less than the concentration of our final solution in Expt. No. 1012 and the disagreement is probably the result of uncertainty in the purity of the adenine and of the $\mathrm{MeOH}$ ). Scruggs et al. calculated the enthalpy of solution at $310 \mathrm{~K}$ for the saturated solution. Applying our value for $\Delta C_{\mathrm{p}}$ to their value for $\Delta H$, we obtain $17.7 \mathrm{~kJ} \cdot \mathrm{mol}^{-1}$ at $298 \mathrm{~K}$ which is 21 percent less than our value, $22.5 \mathrm{~kJ} \cdot \mathrm{mol}^{-1}$, at $8 \mathrm{mmol} \cdot \mathrm{kg}^{-1}$.

The following $\Delta C_{p}$ values were determined for reactions of adenine:

in aqueous $\mathrm{HCl}\left(1.0 \mathrm{~mol} \cdot \mathrm{L}^{-1}\right),(107 \pm 3) \mathrm{J} \cdot \mathrm{mol}^{-1} \cdot \mathrm{K}^{-1}$; in aqueous $\mathrm{NaOH}\left(0.9 \mathrm{~mol} \cdot \mathrm{L}^{-1}\right),(126 \pm 8) \mathrm{J} \cdot \mathrm{mol}^{-1} \cdot \mathrm{K}^{-1}$; in Spectro-grade methanol, $(92.9 \pm 5.3) \mathrm{J} \cdot \mathrm{mol}^{-1} \cdot \mathrm{K}^{-1}$; and in absolute ethanol, $(240 \pm 40) \mathrm{J} \cdot \mathrm{mol}^{-1} \cdot \mathrm{K}^{-1}$.

\section{References}

[1] Kilday, M. V., Enthalpies of Solution of the Nucleic Acid Bases.
1. Adenine in Water, J. Res. Nat. Bur. Stand. (U.S.) 83, No. 4, 347-370 (July-August 1978).

[2] Kilday, M. V., Enthalpies of Solution of the Nucleic Acid Bases, J. Res. Nat. Bur. Stand. (U.S.) 83, No. 6, (a) 2. Thymine in Water, 529-537, (b) 3. Cytosine in Water, 539-546, and (c) 4. Uracil in Water, 547-554, (November-December 1978).

[3] Izatt, R. M., Christensen, J. J., and Rytting, J. H., Chem. Rev. 71, 439-481 (1971).

[4] Albert, A., and Brown, D. J., J. Chem. Soc. 2060-2071 (1954).

[5] Prosen, E. J., and Kilday, M. V., An Adiabatic Solution Calorimeter and Measurements of a Standard Reaction for Solution Calorimetry, J. Res. Nat. Bur. Stand. (U.S.), 77A, (Phys. and Chem.) No. 2, 179-203 (March-April 1973).

[6] Cases, J. C., Parker, V. B., and Kilday, M. V., Enthalpy of Solution of Sodium Nitrite, J. Res. Nat. Bur. Stand. (U.S.) 82, No. 1, 1928 (July-August 1977).

[7] Christensen, J. J., Rytting, J. H., and Izatt, R. M., Biochemistry 9 , 4907-4913 (1970).

[8] Parker, V. B., Thermal Properties of Aqueous Uni-univalent Electrolytes, Nat. Stand. Ref. Data Ser., Nat. Bur. Stand. (U.S.) 2, 66 pages (April 1965).

[9] Scruggs, R. L., Achter, E. K., and Ross, P. D., Biopolymers 11, 1961-1972 (1972). 